\title{
Research
}

\section{Exploring the Contribution of Fiscal Transfers to Protected Area Policy}

\author{
Maud Borie $^{1}, \underline{\text { Raphaël Mathevet }}^{1}$, Aurélien Letourneau $^{1}$, Irene Ring $^{2}, \underline{\text { John D. Thompson }}^{1}$ and $^{\text {Pascal Martv }}{ }^{3}$
}

\begin{abstract}
Biodiversity payments have become an increasingly proposed tool to promote conservation measures. An unexplored issue concerns the potential role of fiscal transfers between the state and infra-national authorities potentially as direct financial incentives for biodiversity conservation. We explore how protected areas can be taken into account in a redistributive fiscal transfer system between the state and local authorities, i.e., municipalities. Different simulations were made in the Mediterranean region of southern France, a major biodiversity hotspot subject to increasing threats. We examined two methods for fiscal transfer: first, a "per hectare" method, based on the surface of the protected area within the boundaries of the municipality and second a "population equivalent" method, in which we convert the surface of protected areas into relative numbers of inhabitants. Our results show that consideration of the population of the municipality in addition to its protected areas' surface can provide a strong incentive to encourage municipalities to designate protected areas. However, this will require increased public funding to buffer financial losses incurred by large municipalities that have a low proportion of their territory within protected areas. We discuss the social feasibility of this tool for green infrastructure implementation and future protected area designation.
\end{abstract}

Key Words: biodiversity; conservation policy; ecological solidarity; fiscal transfer; protected areas; public funding

\section{INTRODUCTION}

In recent years, the development of multilevel governance and the need for more scientific input have been identified as major issues in developing more comprehensive participatory approaches for biodiversity conservation policy (ten Kate 2002, Balmford et al. 2005, Paavola et al. 2009, Jordan and Lenschow 2010). In the European Union, the increasing role of local authorities in the governance of sites designated within the EU Habitats Directive for the Natura 2000 network illustrates how the main actors in policy implementation are embedded in a multilevel system. The engagement of municipalities has in this way become a critical point in the successful implementation of conservation objectives, including those that have been agreed upon in the context of international or national directives.

Municipalities often bear the costs of decisions taken at upper administrative levels, whereas the benefits of biodiversity conservation extend far beyond municipal boundaries. Hence, to ensure their participation, there is a need to compensate municipalities for the costs of biodiversity conservation and to provide incentives to act at the local level. Although numerous environmental incentives focus on land users, such as European agri-environmental schemes and programs supporting the Natura 2000 network, direct financial incentives for local public actors such as municipalities and districts represent a rarely used but potentially efficient direct incentive for biodiversity conservation (e.g., Santos et al. 2012). For municipalities, it is generally much more profitable in terms of raising public revenue to attract new inhabitants and commercial enterprises than to create protected areas with their associated land-use restrictions. What is needed now are direct financial incentives to redress this imbalance. Protected areas remain one of the most common instruments in biodiversity conservation policies; they now cover roughly $12 \%$ of the world's surface (Jenkins and Joppa 2010) and international conventions continue to argue for increasing this cover $(17 \%$ at CBD COP10 in Nagoya in 2010, see UNEP 2011).
However, protected area financing is often limited and we must seek to enhance both the effectiveness and efficiency of protected areas by providing the necessary means of funding if they are to ensure the conservation of biodiversity (Emerton et al. 2006, Fuller et al. 2010). As Ferraro and Kiss (2002) illustrate, this efficiency can be greatly improved with direct financial incentives for conservation. Moreover, integrating protected areas more directly into the social and economic tissue of local territories could go a long way to improving their social acceptance (Mathevet et al. 2010).

In this context, the use of fiscal transfers between the state and local authorities for ecological purposes has been identified as an innovative instrument to encourage municipalities to maintain and create protected areas. Although fiscal transfers are commonly used by states to provide funding to local authorities for socioeconomic motives, benefits arising from protected areas are accessible to everyone and contribute to the welfare of the population as a whole, hence the idea of mobilizing this instrument also for ecological motives. In Brazil, since the early 1990 s, a number of states consider protected areas as one of the indicators distributing state level value-added taxes back to the municipal level. At least 16 Brazilian states have already tested and implemented such an approach to compensate municipalities for the costs arising from protected areas (May et al. 2002, Ring 2008a). More recently, following the modification of its fiscal law in 2007, Portugal became the first country in Europe to set up such an initiative to encourage biodiversity protection (Santos et al. 2012). In addition to these concrete steps taken in Brazil and Portugal, simulations have been carried out in other countries such as Germany, Switzerland, and Indonesia (Köllner et al. 2002, Ring 2008b, Mumbunan et al. 2012).

We explore the role of fiscal transfers to enhance the conservation policy of local authorities. Specifically we examine how the development of an ecological criterion and its inclusion within an existing fiscal transfer system from the national government 
in France to municipalities in the Mediterranean region of southern France could provide a novel financial incentive to encourage local actors to designate protected areas.

\section{THE EXISTING FISCAL TRANSFER SYSTEM BETWEEN THE STATE AND MUNICIPALITIES IN FRANCE}

Every year since 1979, municipalities throughout France have received public funding (the DGF) from the national government. This allocation is the main means of fiscal transfer from the state to municipalities. Since 2003, with the integration of a principle of equality among local authorities into the French Constitution, the DGF has become a major distributive tool for the implementation of an equalization mechanism for public spending (Guengant and Josselin 2006). In 2011, the DGF devoted to municipalities was calculated on the basis of numerous criteria and represents the sum of two main components: (1) a lump-sum allocation that represents more than $85 \%$ of the total amount to be distributed and (2) an equalization allocation.

The lump-sum allocation (1) has five main elements. First, it contains a base-line amount that depends on the number of inhabitants in the municipality and can reach up to $€ 128$ per inhabitant. This is the most important component. Second, the allocation is proportional to the surface area of the municipality and the local conditions of the region in which it occurs. In 2011 ordinary areas received $€ 3.22$ per ha, mountainous areas $€ 5.37$ per ha, whereas overseas territories received three times the "ordinary" amount per hectare. Third, there is an allocation that aims to compensate municipalities for the suppression or reduction of other income sources, such as the local business tax. Fourth, there is a complementary allocation that seeks to temporally stabilize the amount of the lump-sum allocation. Finally, municipalities in the core area of a national park or within the perimeter of a marine park receive an "ecological allocation" for the protection of these areas. The equalization allocation (2) is based on a principle of solidarity and distributive equity. It compensates for differences between rural and urban areas and also between municipalities whose fiscal capacity is lower than the average national fiscal capacity.

These two components illustrate how the DGF allows municipalities to perform their public functions in an appropriate manner and also seeks to reduce inequalities among them. Although this allocation integrates socioeconomic inequalities among municipalities, ecological considerations remain marginal. In March 2008, it was estimated that there are 36,783 municipalities in the French territory with 25,000 having less than 700 inhabitants (Bonnard 2009) and only 150 municipalities were eligible for the ecological allocation. Although a total of $€ 13.6$ billion was distributed to French municipalities via the DGF in 2011 , only $0.02 \%$ of this amount was attributed on the basis of ecological considerations, i.e., presence in a national park.

Prior to 2007, the DGF did not even have an ecological component. It was only following the 2006 reform of the law for national parks, that this ecological allocation was introduced (Government of France 2006, 2011) to integrate the surface area of the municipality in the core area of the National Park where regulatory protection is enforced. The formula, used for the calculation of the ecological allocation is the following:

Ecological allocation $=[$ (municipality's surface area in the core area $x$ coefficient) / municipality's total surface] x Point Value.
In this equation:

Point Value $=$ sum of money to be distributed $/ \Sigma[($ the total surface area of different municipalities in the core areas $\mathrm{x}$ coefficient) / total surface area of eligible municipalities].

Here, the value of the coefficient is 1 if the overall core area of the National Park is $<5000 \mathrm{~km}^{2}$ or 2 if the core area is $>5000 \mathrm{~km}^{2}$.

In this way, the ecological allocation takes into consideration relative land-use restrictions due to protected areas and is not determined on a per hectare basis. The same approach has been adopted in Brazil with the ICMS Ecologico procedure. However, the state government retains a certain degree of freedom to decide which ecological indicators they may use (May et al. 2002, Ring 2008a).

\section{SIMULATION METHOD: INCLUDING AN ECOLOGICAL CRITERION IN THE FISCAL TRANSFER SYSTEM}

Only two types of protected areas, national park core areas and marine parks, are currently included in the calculation of the DGF in France. Less than $0.5 \%$ of municipalities in France thus receive an ecological allocation. However, other categories of protected areas also involve land-use restrictions. One of the main questions regarding the introduction of a biodiversity criterion concerns the types of protected areas to be taken into consideration. We thus performed simulations that integrated different types of protected areas including those with strict nature conservation objectives and regulatory control and those that are more flexible with regard to human activities, with control often based on contracts.

To avoid double counting due to spatial overlap of different types of protection, we ranged all protected area categories from the most restrictive with regard to constraints over land use to the most flexible. In our study this range was as follows: national park core areas, national nature reserves, regional nature reserves, sites purchased by the coastal conservatory, Natura 2000 sites, regional natural parks, and biosphere reserves. This means that if a hectare was both in a regional nature reserve and in a Natura 2000 site, it was counted only in the first category. In our analysis each hectare was only counted once. The underlying normative assumption regarding this ranking was that it is more costly for municipalities to maintain protected areas with high restrictions over land use: a hectare situated in the core area of a national park was thus given more value than a hectare in the buffer zone of a biosphere reserve.

The objective of our simulations was to examine whether the integration of a more robust ecological criterion allowed fiscal transfers to be redistributed among municipalities. For this purpose, we chose the Languedoc-Roussillon and ProvenceAlpes-Côte-d'Azur administrative regions in the south of France. Both encompass mountainous areas with national parks and together they cover the entire Mediterranean coastline of metropolitan France. In 2010, $5 \%$ of their area was protected with strict conservation objectives (national park, reserves, and land bought by the coastal conservancy), $12 \%$ with protection aimed at the reconciliation of biodiversity conservation and economic activities (e.g., regional natural parks and biosphere reserves), and $\sim 30 \%$ by Natura 2000 sites, which rely on a contractual approach with land users and owners in France. Figure 1 shows the distribution of protected areas in the study region. As expected, 
Fig. 1. Land use and spatial distribution of the different types of protected areas in southern France (Languedoc-Roussillon and Provence-Alpes-Côte d'Azur regions).

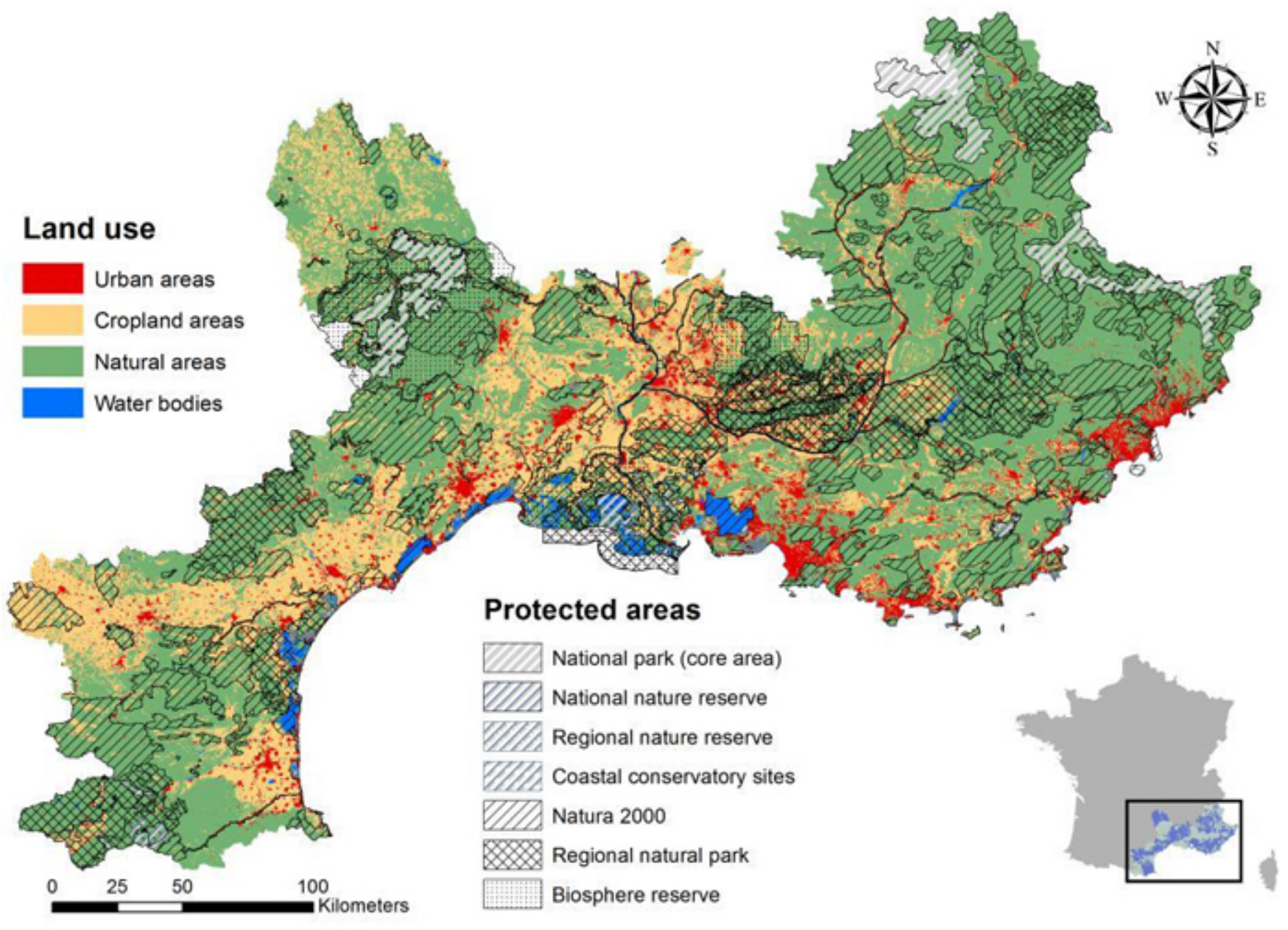

we observed a high correlation between the type of land use and zones under protection. Although the majority of protected areas were situated in natural areas, especially in mountainous areas or coastlands, the map also shows zones where no strict protection regulation is applied despite their high biodiversity values, cropland areas in particular. The study region comprised high plant species diversity and endemism and has been identified as one of the 25 global biodiversity hotspots (Médail and Quezél 1999, Myers et al. 2000). Our sample included 2508 municipalities among which $50 \%$ had less than 500 inhabitants and $48 \%$ were situated in mountainous areas (Table 1).

Using the existing fiscal transfer system in France, we tested two methods: in the first method (PH) the allocation is made proportional to the surface area of the municipality, whereas in the second method (PE) it is proportional to human population size. We highlight the fact that the amount of money to be redistributed in the second case is more important: roughly $50 \%$ of the total DGF amount is distributed according to the population component ( $€ 6$ billion) while only $2 \%$ is distributed according to the surface of the municipalities ( $€ 220$ million). In both methods, the fundamental idea is to give more weight to areas situated in strictly protected areas because they are associated with higher land-use restrictions and thus higher opportunity costs for a given municipality. Instead of extending the existing ecological allocation, which would lead to an inacceptable increase in public funding, we acknowledge the fact that public funding is limited and propose two approaches that do not depend on increased public revenues.

To explore which protected areas should be taken into consideration we decided to test each method in two different scenarios: one that included Natura 2000 sites (S1) and a second that excluded them (S2). The idea was to test the fiscal impact of this emblematic and widespread policy tool for biodiversity conservation in the EU on municipal budgets. In the south of France, this is the policy tool which is the most commonly used (Table 1). In addition to the question regarding which types of protected areas should be taken into consideration, there was also the question of the weighting associated with each category of protected area. 
Table 1. Number of inhabitants in municipalities and percentage of their surface under different types of protection in southern France (Languedoc-Roussillon and Provence-Alpes-Côte d'Azur regions).

\begin{tabular}{|c|c|c|c|c|c|c|c|c|c|}
\hline $\begin{array}{l}\text { Number of } \\
\text { Municipalities }\end{array}$ & & $\begin{array}{c}\% \text { of } \\
\text { Municipalities }\end{array}$ & $\begin{array}{l}\text { National } \\
\text { Parks } \\
(\% \text { area })\end{array}$ & $\begin{array}{l}\text { National } \\
\text { Nature } \\
\text { Reserve } \\
\text { (\% area) }\end{array}$ & $\begin{array}{l}\text { Regional } \\
\text { Nature } \\
\text { Reserve } \\
\text { (\% area) }\end{array}$ & $\begin{array}{l}\text { Sites of the } \\
\text { Coastal } \\
\text { Conservatory } \\
\text { ( } \% \text { area })\end{array}$ & $\begin{array}{c}\text { Natura } 2000 \\
\text { sites } \\
(\% \text { area })\end{array}$ & $\begin{array}{c}\text { Regional } \\
\text { Nature Parks } \\
(\% \text { area })\end{array}$ & $\begin{array}{c}\text { Biosphere } \\
\text { Reserves } \\
(\% \text { area })\end{array}$ \\
\hline $\begin{array}{l}<500 \\
\text { inhabitants }\end{array}$ & 1260 & $50.24 \%$ & $5.73 \%$ & $0.63 \%$ & $0.12 \%$ & $0.02 \%$ & $37.78 \%$ & $8.13 \%$ & $2.92 \%$ \\
\hline $\begin{array}{l}500-200,000 \\
\text { inhabitants }\end{array}$ & 1245 & $49.64 \%$ & $1.98 \%$ & $0.90 \%$ & $0.09 \%$ & $0.75 \%$ & $25.35 \%$ & $9.64 \%$ & $3.21 \%$ \\
\hline $\begin{array}{l}>200,000 \\
\text { inhabitants }\end{array}$ & 3 & $0.12 \%$ & $0.00 \%$ & $0.00 \%$ & $0.00 \%$ & $1.85 \%$ & $22.59 \%$ & $0.00 \%$ & $0.00 \%$ \\
\hline $\begin{array}{l}\text { Nonmountain } \\
\text { area }\end{array}$ & 1307 & $52.11 \%$ & $0.02 \%$ & $1.03 \%$ & $0.11 \%$ & $0.95 \%$ & $25.21 \%$ & $7.36 \%$ & $2.10 \%$ \\
\hline $\begin{array}{l}\text { Mountain } \\
\text { area }\end{array}$ & 1201 & $47.89 \%$ & $6.56 \%$ & $0.56 \%$ & $0.10 \%$ & $0.03 \%$ & $35.15 \%$ & $10.30 \%$ & $3.89 \%$ \\
\hline
\end{tabular}

To test the sensibility of the model and the differences among municipalities that will receive an increase in their allocation due to a fiscal transfer ("winners") compared to those whose allocation declines ("losers"), we first conducted simulations with four different weightings (Table 2). W1 gives an equally high weight to the three categories of protected areas with strict conservation objectives and a zero weight to all others; W2 takes into consideration the degree of land-use restriction in each type of protected area and thus the opportunity cost for municipalities associated with protected areas; W3 gives more value to highly regulated hectares and zero weight to the others; and W4 gives the same weight to all types of protected areas. Following this test, we selected W1 and W2 for our simulations. We excluded W3 because it did not make any sense with our prior assumption: hectares with higher land-use restrictions should be given more weight because they are associated with higher costs. For the same reason we decided not to work with W4 because this weighting was not gradual and did not take into consideration the differences between protected areas in terms of restrictions over land use. However, conducting this test with four weightings in the beginning allowed us to test the sensibility and the responsiveness of our model.

For the two methods, we calculated the percentage of "winners" and "losers" among municipalities by calculating for each municipality a global allocation $(\mathrm{G})$ composed of its population allocation $(P)$ and its surface allocation $(S): G=P+S$. In the first method, we redistributed $\mathrm{S}$ while $\mathrm{P}$ remained unchanged and in the second method we redistributed $\mathrm{P}$ while $\mathrm{S}$ remained unchanged. In each case, the variation of $G$ allowed us to estimate the number of "winners" and "losers" for each scenario.

\section{Method 1: redistribution on a per hectare (PH) basis with constant budget}

This method builds on the existing amount of fiscal transfers allocated to municipalities according to their surface. We redistributed the money allocated to municipalities as a function of their surface area $(S)$ in which we made a distinction between areas with or without a protection status. The municipalities $(48 \%)$ situated in mountainous areas received $€ 5.37$ per hectare and municipalities situated in nonmountainous areas received $€ 3.22$ per hectare. In order not to penalize mountainous areas we respected this rule and calculated $\mathrm{S}$ for each municipality. This gave us two separate global budgets: one for municipalities in mountainous areas $\left(\mathrm{S}_{1}=\Sigma \mathrm{S}_{\mathrm{sm}}\right)$ and one for municipalities situated in nonmountainous areas $\left(\mathrm{S}_{2}=\Sigma \mathrm{S}_{\mathrm{snm}}\right)$. For each cluster we redistributed the overall budget weighted by the type of protected area. As outlined above, we tested S1 and S2 with W1 and W2. This gave us four different scenarios; for each one we looked at the percentage of "winners" and "losers" by looking at the variation of $\mathrm{G}$ for each municipality.

Table 2. Weight attributed to each type of protected area in the two approaches of simulation of green fiscal transfers to municipalities in southern France.

\begin{tabular}{|c|c|c|c|c|c|c|c|}
\hline Weight & $\begin{array}{l}\text { National } \\
\text { Park } \\
\text { (core } \\
\text { area) }\end{array}$ & $\begin{array}{l}\text { National } \\
\text { Nature } \\
\text { Reserve }\end{array}$ & $\begin{array}{l}\text { Regional } \\
\text { Nature } \\
\text { Reserve }\end{array}$ & $\begin{array}{l}\text { Coastal } \\
\text { Conse- } \\
\text { rvatory } \\
\text { site }\end{array}$ & $\begin{array}{c}\text { EU } \\
\text { Natura } \\
2000 \\
\text { site }\end{array}$ & $\begin{array}{c}\text { Regional } \\
\text { Natural } \\
\text { Park }\end{array}$ & $\begin{array}{l}\text { UNES- } \\
\text { CO } \\
\text { Biosph- } \\
\text { ere } \\
\text { Reserve }\end{array}$ \\
\hline W1 & 1.0 & 1.0 & 1.0 & 0.0 & 0.0 & 0.0 & 0.0 \\
\hline W2 & 0.6 & 0.5 & 0.5 & 0.3 & 0.3 & 0.2 & 0.1 \\
\hline W3 & 0.0 & 0.0 & 0.0 & 0.0 & 1.0 & 1.0 & 1.0 \\
\hline W4 & 0.5 & 0.5 & 0.5 & 0.5 & 0.5 & 0.5 & 0.5 \\
\hline
\end{tabular}

Method 2: redistribution based on population equivalent basis (PE) with constant budget

This method builds on the population allocation $(\mathrm{P})$ given to municipalities according to their population. We made use of the approach proposed by Ring (2008b) in Saxony, Germany. Hectares under protection were converted into virtual inhabitants with higher or lower weights according to their category of protected area.

In our study area in 2011, municipalities with less than 500 inhabitants received $€ 64 /$ inhabitant, municipalities with 500 to 200 000 inhabitants received between $€ 64$ and $€ 128 /$ inhabitant $^{[1]}$, and municipalities with more than 200,000 inhabitants received $€ 128 /$ inhabitant. The larger the local population, the more a municipality receives per inhabitant because it is assumed that larger municipalities have higher fiscal needs. Taking into consideration these categories, we calculated $\mathrm{P}$ for each municipality and assumed 
Table 3. Overview of the results for all scenarios of green fiscal transfers. $\mathrm{m}=$ mean, $\mathrm{M}=$ median, and $\mathrm{SD}=\mathrm{standard}$ deviation, absolute numbers in euros. N2000 = Natura 2000.

\begin{tabular}{|c|c|c|c|c|c|c|c|c|c|c|c|}
\hline & & \multirow[b]{2}{*}{ Scenario } & \multirow[b]{2}{*}{ Weight } & \multicolumn{4}{|c|}{ Winners } & \multicolumn{4}{|c|}{ Losers } \\
\hline & & & & $\%$ & $\mathrm{~m}$ & M & SD & $\%$ & $\mathrm{~m}$ & $\mathrm{M}$ & SD \\
\hline A & $\begin{array}{l}\text { With } \\
\text { N2000 }\end{array}$ & $\begin{array}{c}\text { Per } \\
\text { hectare } \\
\text { basis }(\mathrm{PH})\end{array}$ & W1 & $9 \%$ & $11 \%$ & $0 \%$ & $18 \%$ & $86 \%$ & $-2 \%$ & $0 \%$ & $3 \%$ \\
\hline & (S1) & & & & 5172 & 446 & 8868 & & -568 & -95 & 982 \\
\hline B & & & W2 & $39 \%$ & $\begin{array}{c}8 \% \\
2893\end{array}$ & $\begin{array}{c}5 \% \\
1611\end{array}$ & $\begin{array}{c}8 \% \\
4160\end{array}$ & $61 \%$ & $\begin{array}{c}-6 \% \\
-1849\end{array}$ & $\begin{array}{l}-1 \% \\
-863\end{array}$ & $\begin{array}{c}8 \% \\
2323\end{array}$ \\
\hline $\mathrm{C}$ & & $\begin{array}{l}\text { Population } \\
\text { equivalent }\end{array}$ & W1 & $7 \%$ & $3281 \%$ & $1960 \%$ & $3909 \%$ & $48 \%$ & $-17 \%$ & $-16 \%$ & $11 \%$ \\
\hline D & & & W2 & $58 \%$ & $\begin{array}{c}471 \% \\
173,945\end{array}$ & $\begin{array}{l}1044 \% \\
88,354\end{array}$ & $\begin{array}{c}431 \% \\
284,729\end{array}$ & $29 \%$ & $\begin{array}{c}-18 \% \\
-346,932\end{array}$ & $\begin{array}{c}-17 \% \\
-35,474\end{array}$ & $\begin{array}{c}11 \% \\
2,364,016\end{array}$ \\
\hline $\mathrm{E}$ & $\begin{array}{l}\text { Without } \\
\text { N2000 }\end{array}$ & $\begin{array}{c}\text { Per } \\
\text { hectare } \\
\text { basis }(\mathrm{PH})\end{array}$ & W1 & $6 \%$ & $18 \%$ & $13 \%$ & $19 \%$ & $94 \%$ & $-2 \%$ & $0 \%$ & $2 \%$ \\
\hline & (S2) & & & & 8405 & 4603 & 10,154 & & -509 & -129 & 806 \\
\hline $\mathrm{F}$ & & & W2 & $17 \%$ & $\begin{array}{c}6 \% \\
2641\end{array}$ & $\begin{array}{c}2 \% \\
1198\end{array}$ & $\begin{array}{c}8 \% \\
4139\end{array}$ & $83 \%$ & $\begin{array}{l}-2 \% \\
-551\end{array}$ & $\begin{array}{c}0 \% \\
-264\end{array}$ & $\begin{array}{l}2 \% \\
747\end{array}$ \\
\hline G & & $\begin{array}{l}\text { Population } \\
\text { equivalent } \\
\text { (PE) }\end{array}$ & W1 & $7 \%$ & $\begin{array}{c}3281 \% \\
1,614,877\end{array}$ & $1960 \%$ & $3909 \%$ & $48 \%$ & $-17 \%$ & $-16 \%$ & $1,872,652$ \\
\hline $\mathrm{H}$ & & & W2 & $26 \%$ & $\begin{array}{c}855 \% \\
424,266\end{array}$ & $\begin{array}{c}290 \% \\
154,669\end{array}$ & $\begin{array}{c}1381 \% \\
801,366\end{array}$ & $40 \%$ & $\begin{array}{c}-17 \% \\
-269,375\end{array}$ & $\begin{array}{c}-17 \% \\
-27,531\end{array}$ & $\begin{array}{c}11 \% \\
2,597,121\end{array}$ \\
\hline
\end{tabular}

an overall global population allocation. This amount was redistributed including the "virtual inhabitants" resulting from the conversion of hectares under protected areas. In order not to disadvantage small municipalities $(<500$ inhabitants) with low revenues we worked with a minimum amount of $€ 64 /$ inhabitant; we assumed that small municipalities were already very dependent on public funding and could not afford to "lose" money. Hence, the money that was redistributed came from the budget of larger municipalities ( $>500$ inhabitants). It is crucial to note that with this method, and when we took into consideration Natura 2000 sites, we "created" more than 260,000 virtual inhabitants with W1 and 830,000 with W2, which correspond, respectively, to an increase in $4 \%$ and $11 \%$ of the total population of the regions, most of them situated in rural areas.

\section{RESULTS}

An overview of the results in both percentage and absolute value for all scenarios and weightings is shown in Table 3. In each case, we considered the number of municipalities receiving increased (winners) and reduced (losers) fiscal transfers to the status quo. For some municipalities the situation remains unchanged, for instance, in scenarios $\mathrm{C}, \mathrm{D}, \mathrm{G}$, and $\mathrm{H}$ in which small municipalities still receive $€ 64 /$ inhabitants even if they do not have protected areas. As expected, in all scenarios but one a higher number of municipalities experienced a decrease in their fiscal transfers, because more than $50 \%$ of the study region is not under protection.

However, there were major differences in the number of winners and losers as well as in the redistribution operated among the simulations. In both approaches there was an important increase in the number of winners when Nature 2000 sites were taken into consideration and in all cases results with $\mathrm{W} 1$ were lower than with W2. With the per hectare (PH) method, up to $39 \%$ of municipalities were winners, among which $46 \%$ were small municipalities (less than 500 inhabitants) and $32 \%$ were medium municipalities (500-200 000 inhabitants). Besides, 31\% were situated in nonmountainous areas and $48 \%$ in mountainous areas. In the population equivalent method (PE) up to $58 \%$ of municipalities were winners with $74 \%$ being small municipalities and $42 \%$ medium municipalities. As expected, with both methods, the redistribution did not favour larger municipalities $(>200,000$ inhabitants); this is the case for the three biggest cities in the study area.

We mapped these results for the scenarios maximizing the number of winners for each approach (all with W2) and in each case we illustrated the difference with the situation in which Natura 2000 sites are not taken into consideration (Fig. 2). In all cases it is the variation of fiscal transfers, for each municipality, that is represented. To allow a visual comparison between both approaches we chose to use the same legend for all the maps. For the $\mathrm{PH}$ approach scenario B maximized the number of winners and we contrasted it with scenario $F$ that did not include Natura 2000 sites. For the PE approach, scenario D maximized the number of winners while scenario H was without Natura 2000 sites. However, although for the PH approach, maps can be interpreted in light of the spatial distribution of protected areas only, to understand the PE approach it is necessary to relate as well to the population density in the study region (Fig. 2).

How are winners and losers distributed across the maps? In all cases, as expected, we observed a correlation between the distribution of protected areas and winners. With W2 even less restricted protected areas are included in the simulations: this explains why although municipalities with highly regulated 
Fig. 2. Spatial distribution of municipalities receiving increased and reduced fiscal transfers (in \%) for four scenarios B, D, F, H in southern France. B and F follow the "per hectare" approach but F disregards Natura 200 sites. D and H follow the "population equivalent" approach but $\mathrm{H}$ disregards Natura 200 sites. The level of regulation of protected areas and the number of inhabitants per municipalities are provided to support interpretation of results. $\mathrm{PH}=$ per hectare approach, $\mathrm{PE}=$ population equivalent method.

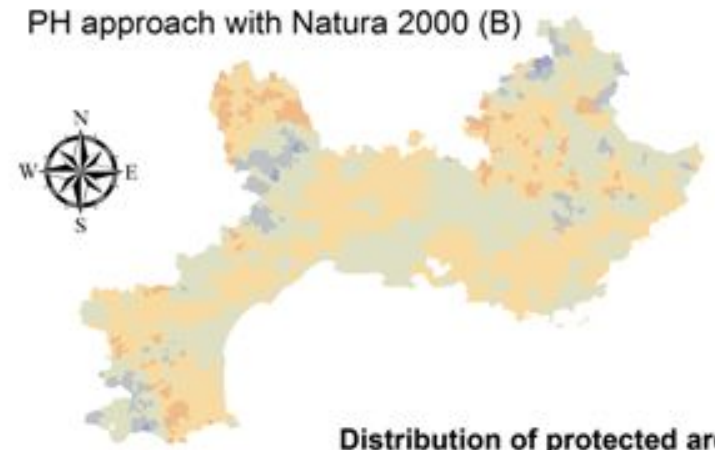

Distribution of protected areas and Legend

$\begin{aligned} \square & <-40 \% \\ & <-20 \% \\ & <0 \% \\ & 0 \% \\ & >0 \% \\ & >20 \% \\ & >40 \% \\ & >60 \% \\ & >80 \% \\ & >100 \%\end{aligned}$

protected areas benefit from a bigger increase in their allocation, other municipalities with less restricted protected areas also benefit from the scheme (but less importantly). For both approaches, the inclusion of Natura 2000 sites made an important difference: it was the most widespread biodiversity policy tool in the study region and it appeared to be a key variable to increase the number of winners; this is highlighted in the maps (Fig. 2). However, it is clear that with the PE approach, changes in fiscal transfers were always more important and the distribution of winners and losers was slightly different than with the $\mathrm{PH}$ approach.

For the PE approach, hectares of protected areas were converted into virtual inhabitants. In our simulation, we assumed that municipalities with less than 500 inhabitants could not afford to experience a decrease in their allocation. For this reason, with this approach, there was no loser among municipalities with less than 500 inhabitants: either their situation remained unchanged or they benefitted from the new situation. Losses were distributed among municipalities with more than 500 inhabitants and without protected areas; these were situated mostly near the highly populated coastline and also in cropland areas with no protection. This was an important difference with the $\mathrm{PH}$ approach in which even the smallest municipalities could experience a decrease if they did not have protected areas. However, the losses/gains experienced with the $\mathrm{PH}$ approach were always relatively small when compared to the PE approach. This is because in the French fiscal transfer system, the population allocation is more important than the surface allocation and although a hectare is "worth" at least $€ 3$, an inhabitant is "worth" at least $€ 64$. This means that converting hectares of protected areas into virtual inhabitants gives more financial weight to protected areas: $\mathrm{G}=\mathrm{P}+\mathrm{S}$, and because $\mathrm{P}$ is more important than $\mathrm{S}$, then the variation in fiscal transfer with the PE approach is always more noticeable. 


\section{DISCUSSION}

In our study, scenario B for the "per hectare" method and scenario $\mathrm{D}$ for the "per inhabitant" method maximized the number of winners. Obviously, all of these scenarios included Natura 2000 sites. With the population equivalent method it is possible to increase even more importantly the number of winners to the extent that almost $60 \%$ of the municipalities receive an increase in their fiscal transfers (scenario D). Our results suggest that to enhance the social acceptability of such redistribution it is worth considering a wide range of protected areas, including both those based on contractual measures such as EU Natura 2000 sites and those areas based on regulatory control.

Our results show that both methods tested in the south of France could provide a direct fiscal incentive for protected area designation. The method based on surface area is clearly more intuitive and less controversial because changes in fiscal transfers are far less important than with the method based on the number of inhabitants, which is more complex and implies greater financial changes. For the per hectare method, our analysis suggests that the W2 weighting method that moderately accounts for different opportunity costs of conservation in relation to the type of protected area, best limits the variation in redistribution among municipalities, indicative that this weighting may be more sound with regard to ecological considerations and is also likely to be the more acceptable on social grounds. More specifically, scenario B minimizes the loss for losers. The important key message here is that it is possible to have a high number of winners associated with losers that incur less individual loss because of the distribution of the loss across municipalities.

However, we found that redistributing fiscal transfers with a population-based allocation is financially more visible than the redistribution of fiscal transfers based on the surface area of the municipality. For example, in scenario B the average allocation for winners is up to $€ 2893$ with a median of $€ 1611$, whereas in scenario $\mathrm{D}$ the average allocation to winners increases by up to $€ 173,945$ with a median of $€ 88,354$. Hence, the per inhabitant method appears to be a more satisfactory method of encouraging municipalities to maintain and possibly designate new protected areas, or at least reduce local resistance to new protected area designation, because transferred amounts are always much more important than with the PH method. However, in terms of human population size, although small- and medium-sized municipalities would generally benefit from this change (1455 municipalities would "win"), the three largest municipalities of the area would experience a decrease of $50 \%$ of their population allocation. This illustrates the limits of working with an assumed constant budget. To be realistic, a buffer is needed to limit such financial losses for these municipalities because they also provide services that benefit to citizens throughout the study area. A potential solution could be to limit the maximum increase in fiscal transfers that winners can get. Some of the winners, i.e., municipalities with a small population and a high surface area under protection, experience a very important increase in their fiscal transfers and by limiting this increase to $100 \%$, for instance, some money could be made available.

However, there is no single method to introduce a biodiversity indicator into the calculation of fiscal transfers. In our simulations we could also imagine a combination between the PH and the PE approaches: they are not necessarily mutually exclusive. Another approach with an increase in public funding would be to extend the existing ecological allocation dedicated to national parks' core areas to other types of protected areas. However, whatever the method this integration will involve additional transactions costs associated with monitoring.

An important issue here is that municipalities are free to use the allocated lump-sum transfers as they wish and there is no obligation to spend it on environmental issues. Although small rural municipalities with low public revenues benefit more from ecological fiscal transfers, there may ultimately be no direct link between this eco-based allocation and environmental actions. This raises the question of whether a reform in fiscal transfers that includes an ecological component will be effective over the long run because there is a risk of losing track of how the transfer is specifically allocated to biodiversity protection. It will thus be necessary to link such fiscal transfers more directly to the conservation goal, i.e., protected area designation and management if we are to get what we pay for. This implies that "greening" fiscal transfers could be a highly visible and effective incentive to designate new protected areas whose conservation effectiveness may decrease over time. An important design criterion to counteract such a negative development would thus be the introduction of an indicator that also considers the quality of protected areas (May et al. 2002, Ring 2008a, Santos et al. 2012).

The fiscal transfer system (DGF) in France is a major tool to mitigate inequalities between municipalities. Because protected areas provide benefits to society in general, greening the fiscal transfer system is consistent with the underlying philosophy of the DGF. Such an initiative could thus be used to recognize the efforts made by municipalities at the local level and contribute to putting into practice the concept of ecological solidarity among different territories in relation to their contribution to biodiversity conservation policies (Mathevet et al. 2010, Thompson et al. 2011). By encouraging and rewarding conservation area creation and management, fiscal transfers could enhance societal commitments to conservation and increase stewardships as the willingness of municipalities to conserve or to be part of a protected area or a green infrastructure. By associating ecological objectives with a financial tool for conservation that enhances the social acceptance of protected areas, such ecological solidarity could become a lasting improvement for conservation policy. Although in general municipalities bear the costs but do not capture all the benefits of conservation, it is neither economically nor socially rational for them to conserve at a socially efficient level, nor to be part of a protected area. In such a situation there is no ecological solidarity. In this respect, ecological fiscal transfers can help correct this imbalance by favoring local public actors and providing compensation for conservation actions. Fiscal transfers can thus become part of a policy-mix and encourage local public actors to engage in conservation by a positive and direct economic incentive from the state that recognizes conservation efforts. They may help municipalities to perceive protected areas as something beneficial and not just an obstacle to development.

\section{CONCLUSION}

Fiscal transfers are used in many countries to redistribute tax incomes from upper to lower levels of government. Introducing an ecological parameter into existing fiscal transfer may be more 
efficient than creating a new law to assess and compensate costs associated with biodiversity conservation (Santos et al. 2012). As the strategic plan of the Convention on Biological Diversity calls for multiple levels of governance and the development of positive incentives measures (UNEP 2011), ecological fiscal transfer schemes could offer an effective option to satisfy the objectives of both biodiversity conservation and the equitable distribution of financial resources to local communities in many parts of the world.

The conditions for a socially and environmentally sound redistribution of fiscal transfers to provide direct incentives for protected area designation need to be further debated. We have presented an approach to assess the contribution of fiscal transfers to protected areas' policy. Effective management of protected areas or integration of conservation and development demands new ways of working and new methods to provide incentives and develop management actions. Used in conjunction with deliberative processes, fiscal transfers can be part of a process of empowering stakeholders to facilitate social learning and nature reconnection (Folke et al. 2011, Mathevet 2012). Obviously it is too early to assess the practical applicability of the proposed approach. Nonetheless, we illustrate how it could represent an effective way of social and economic acknowledgment by society and a means for the state to reward stakeholders that integrate biodiversity issues, for example, stakeholders that are engaged in land stewardships (Chapin et al. 2009). Thought of and made available in this way, fiscal transfers could be more efficient or effective than basic compensation of costs, especially in the context of complex multistakes issues that are observed in protected areas established in cultural landscapes still driven by past and present human-made ecological dynamics.

With the implementation of green infrastructures in Europe or megaparks in Africa, such ecological transfers could enhance the social acceptability of protected areas and provide a concrete meaning to the concept of ecological solidarity. Simulating ecological fiscal transfer is, however, sensitive to both the ways of doing the transfer and the precise conservation goals. More research is thus needed to assess the potential positive and adverse effects of such ecological fiscal transfers in diverse ecological and social contexts. Whatever fiscal transfer methods are to be adopted, they should be carefully monitored and decision makers should remain flexible and capable of revising those that appear to be unequal or less effective than initially projected.

${ }^{[1]}$ For these municipalities, the basic amount of $€ 64$ was weighted by a coefficient (a) that depends on the population of the municipality $(\mathrm{a}=1+0.38431089 * \log$ [Population of the municipality/500]).

Responses to this article can be read online at: http://www.ecologyandsociety.org/issues/responses. $\mathrm{php} / 5716$

\section{Acknowledgments:}

This work was financed by the EU FP7 SCALES Project ("Securing the Conservation of biodiversity across Administrative
Levels and spatial, temporal and Ecological Scales"; Project \#226852, AA).

\section{LITERATURE CITED}

Balmford, A., 1. Bennun, B. ten Brink, David Cooper, I. M. Côté, P. Crane, A. Dobson, N. Dudley, I. Dutton, R. E. Green, R. D. Gregory, J. Harrison, E. T. Kennedy, C. Kremen, N. LeaderWilliams, T. E. Lovejoy, G. Mace, R. May, P. Mayaux, P. Morling, J. Phillips, K. Redford, T. H. Ricketts, J. P. Rodríguez, M. Sanjayan, P. J. Schei, A. S. van Jaarsveld, and B. A. Walther. 2005. The convention on biological diversity's 2010 target. Science 307:212-213.

Bonnard, M. 2009. Les Collectivités Territoriales. La Documentation Française, Paris, France.

Chapin, F. S. III, G. P. Kofinas, and C. Folke. 2009. Principles of ecosystem stewardship: resilience-based natural resource management in a changing world. Springer Verlag, New York, New York, USA.

Emerton, L., J. Bishop, and L. Thomas. 2006. Sustainable financing of protected areas: a global review of challenges and options. International Union for Conservation of Nature, Gland, Switzerland. http://dx.doi.org/10.2305/IUCN.CH.2005.PAG.13. $\underline{\text { en }}$

Ferraro, P. J., and A. Kiss. 2002. Direct payments to conserve biodiversity. Science 298:1718-1719. http://dx.doi.org/10.1126/ science. 1078104

Folke, C., Å. Jansson, J. Rockström, P. Olsson, S. R. Carpenter, F. S. Chapin III, A.-S. Crépin, G. Daily, K. Danell, J. Ebbesson, T. Elmqvist, V. Galaz, F. Moberg, M. Nilsson, H. Österblom, E. Ostrom, A. Persson, G. Peterson, S. Polasky, W. Steffen, B. Walker, and F. Westley. 2011. Reconnecting to the biosphere. Ambio 40:719-738. http://dx.doi.org/10.1007/s13280-011-0184-y

Fuller, R. A., E. McDonald-Madden, K. A. Wilson, J. Carwardine, H. S. Grantham, J. E. M. Watson, C. J. Klein, D. C. Green, and Hugh P. Possingham. 2010. Replacing underperforming protected areas achieves better conservation outcomes. Nature 466:365-367. http://dx.doi.org/10.1038/ nature 09180

Government of France. 2011. Code général des collectivités territoriales - Article L2334-7. Government of France, Paris, France. [online] URL: http://www.legifrance.gouv.fr/affichCodeArticle. do:jsessionid=42C4E2D 88F2F11E8A5FE9B08622023C 9. tpdjo $07 \mathrm{~V} 1$ ? idArticle $=$ LEGIARTI000025076151\&cidTexte $=$ LEGITEXT000006070633\&categorieLien $=i d \&$ dateTexte $=20121231$

Government of France. 2006. LOI $n^{\circ}$ 2006-436 du 14 avril 2006 relative aux parcs nationaux, aux parcs naturels marins et aux parcs naturels régionaux. Government of France, Paris, France. [online] URL: http://www.legifrance.gouv.fr/affichTexte.do?cidTexte= JORFTEXT000000609487\&dateTexte $=\&$ categorieLien $=\mathrm{id}$

Guengant, A., and J. M. Josselin. 2006. Réforme constitutionnelle des finances locales: quels sens donner au principe d'égalité? Revue d'Économie Régionale \& Urbaine 5:667-682. http://dx.doi. org/10.3917/reru.065.0667 
Jenkins, C. N., and L. Joppa. 2009. Expansion of the global terrestrial protected area system. Biological Conservation 142:2166-2174. http://dx.doi.org/10.1016/j.biocon.2009.04.016

Jordan, A., and A. Lenschow. 2010. Environmental policy integration: a state of the art review. Environmental Policy and Governance 20(3):147-158.

Köllner, T., O. Schelske, and I. Seidl. 2002. Integrating biodiversity into intergovernmental fiscal transfers based on cantonal benchmarking: a Swiss case study. Basic and Applied Ecology 3(4):381-391. http://dx.doi.org/10.1078/1439-1791-00104

Mathevet, R. 2012. La solidaritéécologique. Ce lien quinous oblige. Actes Sud, Paris, France.

Mathevet, R., J. Thompson, O. Delanoë, M. Cheylan, C. GilFourrier, and M. Bonnin. 2010. La solidarité écologique: un nouveau concept pour la gestion intégrée des parcs nationaux et des territoires. Natures Sciences Sociétés 18(4):424-433. http://dx. doi.org/10.1051/nss/2011006

May, P. H., F. Veiga Neto, V. Denardin, and W. Loureiro. 2002. Using fiscal instruments to encourage conservation: municipal responses to the 'ecological' value-added tax in Paraná and Minas Gerais, Brazil. Pages 173-199 in S. Pagiola, J. Bishop, and N. Landell-Mills, editors. Selling forest environmental services: market-based mechanisms for conservation and development. Earthscan, London, UK.

Médail, F., and P. Quezél. 1999. Biodiversity hotspots in the Mediterranean basin: setting global conservation priorities. Conservation Biology 13(6):1510-1513. http://dx.doi.org/10.1046/ j.1523-1739.1999.98467.X

Mumbunan, S., I. Ring, and T. Lenk. 2012. Ecological fiscal transfers at the provincial level in Indonesia. UFZ Discussion Paper No. 06/2012. Helmholtz Centre for Environmental Research UFZ, Leipzig, Germany.

Myers, N., R. A. Mittermeier, C. G. Mittermeier, G. A. B. da Fonseca, and J. Kent. 2000. Biodiversity hotspots for conservation priorities. Nature 403(6772):853-858. http://dx.doi.org/10.1038/35002501

Paavola, J., A. Gouldson, and T. Kluvánková-Oravská. 2009. Interplay of actors, scales, frameworks and regimes in the governance of biodiversity. Environmental Policy and Governance 19(3):148-158. http://dx.doi.org/10.1002/eet.505

Ring, I. 2008a. Integrating local ecological services into intergovernmental fiscal transfers: the case of the ecological ICMS in Brazil. Land Use Policy 25(4):485-497. http://dx.doi. org/10.1016/j.landusepol.2007.11.001

Ring, I. 2008b. Compensating municipalities for protected areas: fiscal transfers for biodiversity conservation in Saxony, Germany. Gaia-Ecological Perspectives for Science and Society 17:143-151.

Santos, R., I. Ring, P. Antunes, and P. Clemente. 2012. Fiscal transfers for biodiversity conservation: the Portuguese Local Finances Law. Land Use Policy 29(2):261-273. http://dx.doi. org/10.1016/j.landusepol.2011.06.001

Thompson, J., R. Mathevet, O. Delanoë, C. Gil-Fourrier, M. Bonnin, and M. Cheylan. 2011. Ecological solidarity as a conceptual tool for rethinking ecological and social interdependence in conservation policy for protected areas and their surrounding landscape. Comptes Rendus de l'Académie des Sciences, serie Biologies 334(5-6):412-419. http://dx.doi. org/10.1016/j.crvi.2011.02.001

ten Kate, K. 2002. Science and the convention on biological diversity. Science 295:2371-2372. http://dx.doi.org/10.1126/ science. 1070725

United Nations Environment Programme (UNEP). 2011. Report of the tenth meeting of the Conference of the Parties to the Convention on Biological Diversity. UNEP/CBD/COP/10/27. UNEP, Nagoya, Japan. [online] URL: https://www.cbd.int/doc/ meetings/cop/cop-10/official/cop-10-27-en.pdf 